\title{
Influence of Engineering Properties of Soils on Failures and Distresses of Earth Dams in North- Eastern Nigeria
}

\author{
Umaru A. B,,$^{*}$ Sangodoyin A. Y, ${ }^{2}$ B. G. Umara ${ }^{3}$ and Oke I. ${ }^{4}$ \\ ${ }^{1}$ Department of Agricultural and Environmental Engineering, Modibbo Adama University of Technology, Yola, Nigeria \\ ${ }^{2}$ Department of Agricultural and Environmental Engineering, University of Ibadan, Nigeria \\ ${ }^{3}$ Department of Agricultural and Environmental Resources Engineering, University of Maiduguri, Nigeria \\ ${ }^{4}$ Civil Engineering Department, Obafemi Awolowo University, Ile- Ife, Nigeria
}

\begin{abstract}
The stability and water tightness of earth dams depend largely on the engineering properties of the construction materials. There are many cases of dam failures and distresses in north-eastern Nigeria that were not studied and documented. The objective of this study is to determine the influence of engineering properties of soils on failures and distresses of earth dams in the study area.
\end{abstract}

A total of 22 randomly selected earth dams constructed with different soil materials in north-eastern Nigeria were studied. Data were obtained on failure modes using the Association of State Dam Safety Officials method. Soil samples collected were analysed for specific gravity (Gs), particle size distribution, Atterberg limits, compaction, California Bearing Ratio (CBR), permeability, triaxial compression and consolidation tests according to BS1377. The results were analysed using descriptive statistics.

Soil groups for constructing earth dams in the study area ranged from poorly graded sands to silty/clayey sands. Seventy-nine percent of the failed and distressed dams have embankment materials with Coefficient of uniformity of less than 5. Sixty-five percent of failed and distressed dams have Plasticity Index of 0-7. Eighty percent of functional dams have highly compacted soils with maximum dry density ranging from 1.84 to $2.01 \mathrm{Mg} / \mathrm{m}^{3}$. High permeability ranging from 0.018 to $0.110 \mathrm{~m} /$ day influenced $33 \%$ of dam failures. Consolidation tests showed a settlement of $1.18 \mathrm{~mm}$ and $2.29 \mathrm{~mm}$ for functional and failed dam respectively. The Gs (2.41-2.70), CBR values (11-46\%), Cohesion $\left(35-215 \mathrm{kN} / \mathrm{m}^{2}\right)$ and angle of internal friction $\left(3-18^{\circ}\right)$ influenced particular incidents without a trend.

Poor soil selection and application influenced the status of earth dams in north-eastern Nigeria. Soil testing, grouting, soil stabilisation, use of rock ripraps, impervious blankets and maintenance scheduling are suggested to minimise failures and ameliorate distresses.

Keywords: Earth dam, Soil properties, Distress, Failure, Compaction.

\section{INTRODUCTION}

Earth dams are constructed mainly from earth or soil. Earth dams for the storage of water for irrigation have been built since early times. They are of low heights, designed by empirical methods and their construction based on experience. However, developments in soil mechanics and new construction techniques have enabled engineers to build dams of very large heights and different configurations.

The two basic requirements to be satisfied by an earth dam are imperviousness and stability under all conditions of operations. Despite the advantages of materials and cost, earth dams are more susceptible to failures as compared to rigid gravity dams or any other type of dam.

Before the development of the discipline of soil mechanics, earth dams were being designed and constructed on the basis of experience, as no rational basis for their design was available. This probably led to the failure of various such earth embankments. However, in these days, these dams can be designed with a fair degree of theoretical accuracy, provided the properties of the soil placed in the dam are properly controlled. This condition makes the design and construction of such dams thoroughly interdependent. (Garg, 2008)

The recorded damages to earth dams ranges from complete catastrophic failure, resulting in large property damage and loss of life, to relatively minor deterioration or distressnes which may or may not necessitate remedial work. The worst type of failure occurs when the reservoir water suddenly breaks through the embankment and surges downstream in one devastating flood wave. Lesser damages or distresses may in the long run lead to complete failure if left unattended.

On a worldwide scale, it is clear that the objective of constructing stable dams is not always achieved. During the 1900-1965 periods, about $1 \%$ of the 9000 large dams in service throughout the world have failed, and another 2\% have suffered serious accidents (Wrechein and Mambretti, 2009).

Knowledge of the principal lessons learned from failures and damages in the past is an essential part of the training of earth dam designer. (Pumia and Lal, 1992). On the basis of investigation reports on past failures by the same authors, it is possible to categorize the types of failures into three main broad classes namely; Hydraulic (40\%), Seepage $(30 \%)$ and Structural failures $(30 \%)$. Structural failures of earth dams in Nigeria were explained in Umaru et al., (2010). 
Dam failures may occur due to a variety of causes. The most common causes of dam failure are leakage and piping $(35 \%)$, overtopping $(25 \%)$, spillway erosion $(14 \%)$, excessive deformation $(11 \%)$, sliding $(10 \%)$, gate failure (2\%), faulty construction (2\%), and earthquake instability (2\%) (Lukman et al, 2011). The causes and effects of earth dam's failures in north eastern Nigeria were elaborated in Umaru et al.,(2014).

The causes of failure and damage of earth dams can be attributed to lack of adequate studies of the engineering properties of soils during design and construction of such dams. Failures and damages of dams in North Eastern Nigeria that were influenced by geology and hydrometreology factors were discussed in Umaru et al., (2015).

A close look at the causes of most failures show that, the situation may be rescued partly by strict application of engineering properties (physical and hydraulic) of soils and hydrology in the design and construction of the dams. These properties were listed by Murthy (2008) as comprising of bulk density, porosity, permeability, submerged density, particle size distribution, friction, cohesion and water content among others.

Terzaghi was quoted by Arora, (2001) on the recommended side slopes and soil types for embankment dams. Signh, (2001) suggested the slopes and soils for small zoned earth dams on stable foundations. Agarwal, (2000) suggested general guidelines for embankment sections and suitability of soils for earth dams construction.

Brink et al (1982) suggested that the engineering properties of soils used for the construction of the zones of composite earth dams should include; grade of the soil, clay content, hydraulic conductivity, cohesion and angle of internal friction, liquid limit, plasticity index, optimum moisture content, linear shrinkage and dry density. Yohana et $a ., l$ (2003) tested the engineering properties of anthills and found that the properties are similar to what Brink et al (1982) suggested. They recommended its use with mixtures of sand and gravel for the control of seepage in earth dams.

An attempt at approximate classification of core materials on the basis of resistance to concentrated leakage was proposed by Sherard (1953) as; Very Good, Good, Fair, Poor and Very poor Materials. Oskooruchi and Mehdibeigi, (1986) suggested that the selection of soil parameters for designing an earth and rockfill dam should be based on a range of activities from site visit to the selection of factor of safety.

This study attempts to investigate the influence of engineering properties of soils on failures and distresses of earth dams in North Eastern Nigeria.

\section{METHODOLOGY}

Nigeria, a West African Nation lies between Latitude $4^{\circ} 16^{\prime} \mathrm{N}$ and $13^{\circ} 52^{\prime} \mathrm{N}$, and between Longitude $2^{\circ} 49^{\prime} \mathrm{E}$ and $14^{\circ} 37^{\prime}$ E. North Eastern Nigeria (Fig. 1.) encompasses Borno, Yobe, Bauchi, Gombe, Adamawa and Taraba states. It is the home of a rapidly growing population of some 6.5 million Nigerians. Characterized by water scarcity, the climate of the region ranges from Sahel to Sudan Savannah (Adeniji, 2003). The choice for the study area is the availability of dams and their collapse and distressnes.

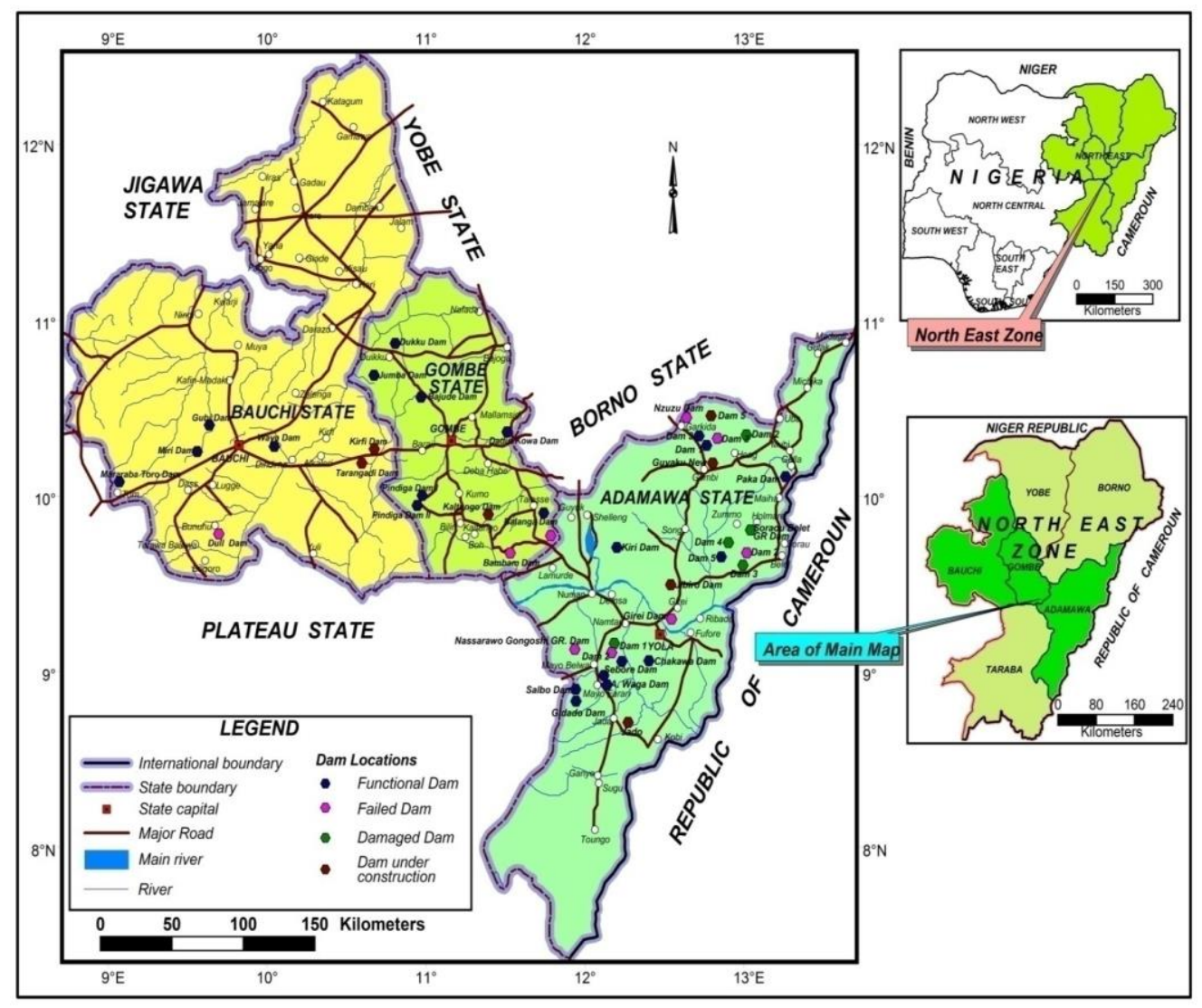

Fig 1. Map of Northeastern Nigeria showing dam locations and status 
In this study, Adamawa, Gombe and Bauchi states were selected out of the six states that make up North Eastern Nigeria. The choice of the sampling is guided by the fact that there are very few dams in Borno and Yobe States and for logistic reasons.

The methodologies adopted for carrying out the study follows the Association of State Dam Safety Officials (ADSO) guideline, (2011) and the BS1377 (1990) as follows;

\section{Field Work}

The field work was carried out in form of visitations to selected dams in the study area for observations, measurements, photographs and picking of soil samples. The materials used were; measuring tape, Global Positioning System (GPS), camera, soil auger, hoe, shovel and scoop for removing and picking of soil samples and cement bags for carrying and transporting the samples to the laboratory. The 22 dams visited were randomly selected across the study area.

\section{Laboratory Experiments}

Soil samples were collected where appropriate, placed in cement bags and transported to the laboratory for the necessary tests. Soil tests were carried out in the soil mechanics laboratory of the Civil Engineering programme at the Abubakar Tafawa Balewa University of Technology (ATBU), Bauchi, Nigeria. Methods of test for soils for civil engineering purposes BS1377(1990) was adopted for the sampling, soil test and analysis.

Based on observation and inspection, soil samples were picked at the appropriate point (failure point, damaged point, stockpiled leftovers) and at different parts (embankment, core, shell, reservoir and spillway) of the dam for the tests and analysis. The different types of scientific and engineering tests that the samples were subjected to were; Specific gravity (Gs), Sieve analysis, Atterberg limits (PL, LL, PI), Compaction test (MDD \& OMC), California Bearing Ratio (CBR), Permeability (K), Triaxial test (C and ф) and Consolidation test. The soil samples were picked from specific functional, distressed and failed dams across the study area.

All the data were analysed using Analysis of Variance (ANOVA) and descriptive statistics.

California Bearing Ratio (CBR)

The CBR values of the materials of construction of the failed dams range from 11 to $46 \%$ (Table 1). The materials exhibit a wide range of behaviors under loading and range from very strong materials like well graded gravel to relatively weak materials like silts. The CBR values of materials of construction of the distressed dams were found to range from 14 to $28 \%$. These materials can also exhibit a wide range of behavior under loading as will be characterized by a relatively strong material like clayed gravel to a relatively weak material like Silt. The CBR values of the materials of construction of the functional dams range from 14 to $36 \%$. Again, these materials exhibit a range of behaviors under loading as shown by relatively strong materials like gravely clay to a weak material like silt. Although the minimum CBR for the failed dams is the lowest, the range is not significantly different from distressed and functional dam soils. This shows that the CBR values alone cannot predict failure, distressnes or functionality of earth dams in the study area, but have influenced particular failures when associated with other soil properties.

Table 1. Some Soil Properties and CBR Values

\begin{tabular}{|c|c|c|c|c|c|c|c|}
\hline $\mathrm{S} / \mathrm{N}$ & Name of Dam & Soil Sample location & Moisture Content (\%) & Bulk Density $\mathrm{Mg} / \mathrm{m}^{3}$ & Dry Density $\mathrm{Mg} / \mathrm{m}^{3}$ & $\begin{array}{l}\text { CBR } \\
(\%)\end{array}$ & Status \\
\hline \multirow[t]{3}{*}{1.} & Girei & SPLW & 6.4 & 2.20 & 2.07 & 46 & Failed \\
\hline & & EM & & & & & \\
\hline & & RSV & - & - & - & - & \\
\hline \multirow[t]{2}{*}{2.} & Guyaku GR Dam 2 & RSV & - & - & - & - & Failed \\
\hline & & EM & & & & & \\
\hline \multirow[t]{2}{*}{3.} & Guyaku GR Dam 5 & IN GULLY & - & - & - & - & Failed \\
\hline & & EM & & & & & \\
\hline 4. & Nzuzu Dam & SPLW & 8.6 & 2.00 & 1.84 & 24 & Failed \\
\hline 5. & NGGR Dam 1(Dalehi) & EM & 14.8 & 1.94 & 1.69 & 20 & Distressed \\
\hline 6. & NGGR Dam 2(Dalehi) & RSV & - & - & - & - & Failed \\
\hline 7. & Ali Walga Dam & EM & 11.3 & 2.18 & 1.96 & 36 & Functional \\
\hline 8. & SBGR Dam 3 & RSV & - & - & - & - & Distressed \\
\hline \multirow[t]{2}{*}{9.} & SBGR Dam 4 & EM & 5.6 & 2.02 & 1.91 & 28 & Distressed \\
\hline & & RSV & - & - & - & - & \\
\hline 10. & Dadinkowa Dam & EM & 10.8 & 2.06 & 1.86 & 21 & Functional \\
\hline 11. & Bambam Dam & EM & 18.5 & 1.76 & 1.49 & 11 & Failed \\
\hline 12. & Pindiga Dam I & EM/RSV & 9.7 & 2.07 & 1.89 & 14 & Functional \\
\hline 13. & Pindiga Dam II & EM/RSV & 13.4 & 1.85 & 1.63 & 31 & Functional \\
\hline 14. & Bojude & EM/RSV & 8.9 & 1.87 & 1.72 & 24 & Functional \\
\hline 15. & Jombo Dam Dukku & EM/RSV & 15.5 & 1.70 & 1.47 & 25 & Functional \\
\hline 16. & Dukku Dam(Kogin Dole) & EM & 6.9 & 2.09 & 1.96 & 25 & Functional \\
\hline 17. & Cham Dam & $\mathrm{EM} / \mathrm{RS}$ & 14.7 & 2.16 & 1.88 & 17 & Failed \\
\hline \multirow[t]{2}{*}{18.} & Waya Dam & EM(SHELL) & 10.8 & 2.07 & 1.87 & 15 & Failed (rptdly) \\
\hline & & EM(CORE) & 8.1 & 2.13 & 1.97 & 20 & \\
\hline
\end{tabular}




\begin{tabular}{|c|c|c|c|c|c|c|c|}
\hline \multirow[t]{2}{*}{19.} & \multirow[t]{2}{*}{ Gubi Dam } & EM(SHELL) & 9.7 & 2.08 & 1.90 & 36 & \multirow[t]{2}{*}{ Functional } \\
\hline & & $\mathrm{EM}(\mathrm{CORE})$ & 12.1 & 2.15 & 1.92 & 34 & \\
\hline 20. & Miri Dam & EM/RSV & 11.8 & 2.15 & 1.92 & 14 & Distressed \\
\hline 21. & Marraraba Ganye Toro Dam & EM/RSV & 11.5 & 2.14 & 1.92 & 21 & Functional \\
\hline \multirow[t]{2}{*}{22.} & Dull Dam & $\mathrm{EM}$ (Left) & 15.9 & 2.00 & 1.73 & 19 & Failed \\
\hline & & EM(Right) & 10.8 & 2.23 & 2.01 & 23 & \\
\hline
\end{tabular}

Soils were not sampled at some dams because of non cooperation of owners and logistic reasons

$\mathrm{KEY} ; \mathrm{EM}=$ Embankment, RSV = Reservoir, SPLW = Spillway

Coefficient of Permeability, $K$

In Table 2, the permeability of the materials of construction of the failed dams range from $1.21 \times 10^{-8}$ to $1.21 \times 10^{-6} \mathrm{~m} / \mathrm{s}$ thus indicating a wide range of permeability phenomena from a practically impermeable material to a poor draining material. The permeability values for the distressed dams range from $1.76 \times 10^{-8}$ to $5.65 \times 10^{-8} \mathrm{~m} / \mathrm{s}$ indicating that the materials are practically impermeable; and are thus excellent for use as construction materials for earth dams in this regard. The range of permeability values for the materials of construction of functional dams was found to be $8.76 \times 10^{-8}$ to $1.82 \times 10^{-7} \mathrm{~m} / \mathrm{s}$ also signifying good materials that are impervious to some extent. About a third of the failed dams have their embankment soil materials with coefficient of permeability between $1.21 \times 10^{-6} \mathrm{~m} / \mathrm{s}$ to $2.10 \times 10^{-7} \mathrm{~m} / \mathrm{s}$, suggesting the susceptibility of such dams to seepage failure. On a study of gully erosion in the north-eastern Nigeria, Obiefuna et al, (1999) obtained similar results.

Table 2. Some Soil Properties and Permeability Values

\begin{tabular}{|c|c|c|c|c|c|c|c|c|}
\hline$\overline{\mathrm{S} / \mathrm{N}}$ & Name of Dam & $\begin{array}{l}\text { Soil Sample } \\
\text { Location }\end{array}$ & $\begin{array}{l}\text { Moisture } \\
\text { Content } \\
(\%) \\
\end{array}$ & $\begin{array}{l}\text { Bulk Density } \\
\rho\left(\mathrm{Mg} / \mathrm{m}^{3}\right)\end{array}$ & $\begin{array}{l}\text { Dry Density, } \rho_{\mathrm{d}} \\
\left(\mathrm{Mg} / \mathrm{m}^{3}\right)\end{array}$ & $\begin{array}{l}\text { Void } \\
\text { Ratio }\end{array}$ & $\begin{array}{l}\text { Permeability, } \\
\mathrm{K}(\mathrm{m} / \mathrm{s})\end{array}$ & Status \\
\hline 1. & Girei & $\begin{array}{l}\text { SPLW } \\
\text { EM } \\
\text { RSV }\end{array}$ & $\begin{array}{l}8.0 \\
18.5 \\
1.31\end{array}$ & $\begin{array}{l}2.17 \\
1.88 \\
1.97\end{array}$ & $\begin{array}{l}2.01 \\
1.59 \\
1.95\end{array}$ & $\begin{array}{l}0.294 \\
0.535 \\
0.323\end{array}$ & $\begin{array}{l}1.21 \times 10^{-6} \\
2.33 \times 10^{-8} \\
2.73 \times 10^{-6}\end{array}$ & Failed \\
\hline 2. & $\begin{array}{l}\text { Guyaku GR } \\
\text { Dam } 2\end{array}$ & RSV & & & & & & Failed \\
\hline 3. & $\begin{array}{l}\text { Guyaku GR } \\
\text { Dam } 5\end{array}$ & $\begin{array}{l}\text { EM } \\
\text { IN GULLY }\end{array}$ & 6.8 & 2.09 & 1.96 & 0.342 & $4.9 \times 10^{-8}$ & Failed \\
\hline $\begin{array}{l}4 . \\
5 .\end{array}$ & $\begin{array}{l}\text { Nzuzu Dam } \\
\text { NGGR Dam } \\
\text { 1(Dalehi) }\end{array}$ & $\begin{array}{l}\text { EM } \\
\text { SPLW } \\
\text { EM }\end{array}$ & $\begin{array}{l}13.7 \\
7.6\end{array}$ & $\begin{array}{l}2.00 \\
2.16\end{array}$ & $\begin{array}{l}2.29 \\
2.01\end{array}$ & $\begin{array}{l}0.135 \\
0.199\end{array}$ & $\begin{array}{l}2.79 \times 10^{-8} \\
5.65 \times 10^{-8}\end{array}$ & $\begin{array}{l}\text { Failed } \\
\text { Distressed }\end{array}$ \\
\hline 6. & $\begin{array}{l}\text { NGGR Dam } \\
\text { 2(Dalehi) }\end{array}$ & RSV & 15.4 & 1.83 & 1.59 & 0.635 & $9.33 x^{-8}$ & Failed \\
\hline 7. & Ali Walga Dam & EM & & & & & & Functional \\
\hline 8. & SBGR Dam 3 & RSV & 11.8 & 2.03 & 1.82 & 0.357 & $2.31 \times 10^{-8}$ & Distressed \\
\hline 9. & SBGR Dam 4 & $\begin{array}{l}\text { EM } \\
\text { RSV }\end{array}$ & $\begin{array}{l}10.8 \\
11.5\end{array}$ & $\begin{array}{l}1.80 \\
2.17\end{array}$ & $\begin{array}{l}1.63 \\
1.95\end{array}$ & $\begin{array}{l}0.552 \\
0.349\end{array}$ & $\begin{array}{l}1.76 \times 10^{-8} \\
1.79 \times 10^{-8}\end{array}$ & Distressed \\
\hline 10. & $\begin{array}{l}\text { Dadinkowa } \\
\text { Dam }\end{array}$ & EM & 21.5 & 2.03 & 1.67 & 0.551 & $8.78 \times 10^{-8}$ & Functional \\
\hline 11. & Bambam Dam & EM/RSV & 12.5 & 1.99 & 1.77 & 0.429 & $2.61 \times 10^{-8}$ & Failed \\
\hline 12. & Pindiga Dam I & EM/RSV & 15.7 & 2.03 & 1.76 & 0.460 & $7.71 \times 10^{-8}$ & Functional \\
\hline 13. & Pindiga Dam II & EM/RSV & 20.1 & 2.63 & 1.67 & 0.614 & $2.02 \times 10^{-8}$ & Functional \\
\hline 14. & Bojude & EM/RSV & 15.6 & 2.03 & 1.76 & 0.534 & $2.46 \times 10^{-8}$ & Functional \\
\hline 15. & $\begin{array}{l}\text { Jombo Dam } \\
\text { Dukku }\end{array}$ & EM/RSV & 6.6 & 2.08 & 1.95 & 0.282 & $4.43 \times 10^{-8}$ & Functional \\
\hline 16. & $\begin{array}{l}\text { Dukku } \\
\text { Dam(Kogin } \\
\text { Dole) }\end{array}$ & EM & 11.1 & 2.13 & 1.92 & 0.354 & $1.82 \times 10^{-7}$ & Functional \\
\hline 17. & Cham Dam & EM/RSV & 1.76 & 1.98 & 1.95 & 0.364 & $3.42 \times 10^{-8}$ & Failed \\
\hline 18. & Waya Dam & $\begin{array}{l}\text { EM(SHELL) } \\
\text { EM(CORE) }\end{array}$ & $\begin{array}{l}14.5 \\
13.9\end{array}$ & $\begin{array}{l}2.04 \\
2.01\end{array}$ & $\begin{array}{l}1.77 \\
1.77\end{array}$ & $\begin{array}{l}0.478 \\
0.469\end{array}$ & $\begin{array}{l}4.29 \times 10^{-6} \\
2.01 \times 10^{-7}\end{array}$ & Failed (rptdly) \\
\hline 19. & Gubi Dam & $\begin{array}{l}\text { EM(SHELL) } \\
\text { EM(CORE) }\end{array}$ & $\begin{array}{l}14.5 \\
7.8\end{array}$ & $\begin{array}{l}2.05 \\
2.03\end{array}$ & $\begin{array}{l}1.79 \\
1.88\end{array}$ & $\begin{array}{l}0.469 \\
0.399\end{array}$ & $\begin{array}{l}3.00 \times 10^{-8} \\
1.23 \times 10^{-8}\end{array}$ & Functional \\
\hline 20. & Miri Dam & EM/RSV & 5.36 & 2.10 & 1.99 & 0.322 & $3.91 \times 10^{-8}$ & Distressed \\
\hline 21. & $\begin{array}{l}\text { Marraraba } \\
\text { Ganye Toro } \\
\text { Dam }\end{array}$ & EM/RSV & 9.3 & 2.03 & 1.86 & 0.452 & $1.64 \times 10^{-8}$ & Functional \\
\hline 22. & Dull Dam & $\begin{array}{l}\text { EM(Left) } \\
\text { EM(Right) }\end{array}$ & $\begin{array}{l}8.84 \\
11.48 \\
\end{array}$ & $\begin{array}{l}2.11 \\
2.10 \\
\end{array}$ & $\begin{array}{l}1.94 \\
1.88 \\
\end{array}$ & $\begin{array}{l}0.289 \\
0.400 \\
\end{array}$ & $\begin{array}{l}1.4 \times 10^{-8} \\
1.21 \times 10^{-8} \\
\end{array}$ & Failed \\
\hline
\end{tabular}

KEY; EM = Embankment RSV = Reservoir SPLW = Spillway 
Shear Strength

The range of values for Cohesion $\mathrm{C}$ and Angle of Internal friction $\phi$ for the dams in the study area are as shown in Table 3.

Table 3. Triaxial Compression Test Results (Quick Undrained)

\begin{tabular}{|c|c|c|c|c|c|}
\hline $\mathrm{S} / \mathrm{N}$ & Name of Dam & $\begin{array}{l}\text { Soil Sample } \\
\text { location }\end{array}$ & $\begin{array}{l}\text { Cohession, } \\
\mathrm{C}\left(\mathrm{kN} / \mathrm{m}^{2}\right)\end{array}$ & $\begin{array}{l}\text { Angle of } \\
\text { Imternal } \\
\text { Friction, } \phi \\
\left(^{\circ}\right)\end{array}$ & Status \\
\hline \multirow[t]{2}{*}{1.} & Girei & SPLW & & & Failed \\
\hline & & $\begin{array}{l}\text { EM } \\
\text { RSV }\end{array}$ & 74 & 5 & \\
\hline \multirow[t]{2}{*}{2.} & Guyaku GR Dam 2 & RSV & & & Failed \\
\hline & & EM & 215 & 3 & \\
\hline 3. & Guyaku GR Dam 5 & $\begin{array}{l}\text { IN GULLY } \\
\text { EM }\end{array}$ & 60 & 20 & Failed \\
\hline 4. & Nzuzu Dam & SPLW & 40 & 13 & Failed \\
\hline 5. & NGGR Dam 1(Dalehi) & EM & 70 & 5 & Distressed \\
\hline 6. & NGGR Dam 2(Dalehi) & RSV & & & Failed \\
\hline 7. & Ali Walga Dam & EM & & & Functional \\
\hline 8. & SBGR Dam 3 & RSV & & & Distressed \\
\hline 9. & SBGR Dam 4 & $\begin{array}{l}\text { EM } \\
\text { RSV }\end{array}$ & & & Distressed \\
\hline 10. & Dadinkowa Dam & EM & 40 & 50 & Functional \\
\hline 11. & Bambam Dam & $\mathrm{EM} / \mathrm{RSV}$ & 100 & 5 & Failed \\
\hline 12. & Pindiga Dam I & $\mathrm{EM} / \mathrm{RSV}$ & 85 & 13 & Functional \\
\hline 13. & Pindiga Dam II & $\mathrm{EM} / \mathrm{RSV}$ & 100 & 8 & Functional \\
\hline 14. & Bojude & $\mathrm{EM} / \mathrm{RSV}$ & 62 & 7 & Functional \\
\hline 15. & Jumbo Dam Dukku & EM/RSV & & & Functional \\
\hline 16. & Dukku Dam(Kogin Dole) & $\mathrm{EM}$ & 70 & 14 & Functional \\
\hline 17. & Cham Dam & $\mathrm{EM} / \mathrm{RS}$ & 95 & 23 & Failed \\
\hline \multirow[t]{2}{*}{18.} & Waya Dam & EM(SHELL) & 35 & 18 & Failed (rptdly) \\
\hline & & $\mathrm{EM}(\mathrm{CORE})$ & 123 & 10 & \\
\hline \multirow[t]{2}{*}{19.} & Gubi Dam & EM(SHELL) & 61 & 18 & Functional \\
\hline & & $\mathrm{EM}(\mathrm{CORE})$ & 40 & 24 & \\
\hline 20. & Miri Dam & $\mathrm{EM} / \mathrm{RSV}$ & 60 & 17 & Distressed \\
\hline 21. & $\begin{array}{l}\text { Marraraba Ganye Toro } \\
\text { Dam }\end{array}$ & EM/RSV & 45 & 10 & Functional \\
\hline \multirow[t]{2}{*}{22.} & Dull Dam & $\mathrm{EM}($ Left $)$ & 70 & 20 & Failed \\
\hline & & EM(Rigth) & 100 & 13 & \\
\hline
\end{tabular}

Key; Em = Embankment, $R s v=$ Reservoir, Splw = Spillway

The soil materials for the failed dams have $\mathrm{C}$ and $\phi$ values in the range of 35 to $215 \mathrm{kN} / \mathrm{m}^{2}$ and 3 to $18^{\circ}$ respectively, showing an excellent soil as far as the shear strength properties are concerned. The ranges of $\mathrm{C}$ and $\phi$ for the distressed dams was found to be $60-70 \mathrm{kN} / \mathrm{m}^{2}$ and $5-17^{\circ}$ respectively, this indicate a good shear strength property for embankment in dam construction. The functional dams have their range of $\mathrm{C}$ and $\phi$ as $40-100 \mathrm{kN} / \mathrm{m}^{2}$ and $8-50^{\circ}$ respectively. This also indicates a material with good shearing strength characteristics. Ironically, the shear strength of the failed dams seems to be better than the distressed and functional dams. Thus, shear strength parameters alone may not be a good indication for failure, distress or functionality of dams in the study area.
Atterberg Limits and Plasticity Index (PI)

In Table 4 the PI values for failed dams were found to vary from 0 to 20 indicating a range of behavior for the construction materials from non-plastic to highly plastic. The range of PI values for distressed dams was 0 to 11 , showing a range of behaviors for the embankment materials from non-plastic to soils of medium plasticity. PI values for the functional dams were found to be similar to the failed dams (0 - 21) indicating non-plastic to highly plastic materials. Sixty five percent of failed and distressed dams have their Plasticity indexes between 0 and 7 meaning failures and distresses affect embankments whose soil materials are of low plasticity. 
Table 4. Atterberg Limits (Cone Test)

\begin{tabular}{|c|c|c|c|c|c|c|}
\hline $\mathrm{S} / \mathrm{N}$ & Dam & Soil Sample location & Liquid Limit, LL (\%) & Plastic Limit,PL (\%) & Plasticity Index,PI & Status \\
\hline \multirow{3}{*}{1.} & Girei & SPLW & 13 & - & - & Failed \\
\hline & & EM & 19 & - & - & \\
\hline & & RSV & 18 & - & - & \\
\hline \multirow[t]{2}{*}{2.} & Guyaku GR Dam 2 & RSV & - & - & - & Failed \\
\hline & & EM & 22 & 15 & 7 & \\
\hline \multirow[t]{2}{*}{3.} & Guyaku GR Dam 5 & IN GULLY & 25 & 23 & 2 & Failed \\
\hline & & EM & 30 & 23 & 7 & \\
\hline 4. & Nzuzu Dam & SPLW & 24 & 18 & 6 & Failed \\
\hline 5. & NGGR Dam 1(Dalehi) & EM & 24 & 14 & 10 & Distressed \\
\hline 6. & NGGR Dam 2(Dalehi) & RSV & 16 & - & 0 & Failed \\
\hline 7. & Ali Walga Dam & EM & 19 & - & 0 & Functional \\
\hline 8. & SBGR Dam 3 & RSV & 30 & 19 & 11 & Distressed \\
\hline \multirow[t]{2}{*}{9.} & SBGR Dam 4 & EM & 26 & - & 0 & Distressed \\
\hline & & RSV & 9 & - & 0 & \\
\hline 10. & Dadinkowa Dam & EM & 27 & 16 & 11 & Functional \\
\hline 11. & Bambam Dam & EM & 47 & 27 & 20 & Failed \\
\hline 12. & Pindiga Dam I & EM/RSV & 46 & 25 & 21 & Functional \\
\hline 13. & Pindiga Dam II & EM/RSV & 24 & 21 & 3 & Functional \\
\hline 14. & Bojude & $\mathrm{EM} / \mathrm{RSV}$ & 25 & 15 & 10 & Functional \\
\hline 15. & Jombo Dam Dukku & EM/RSV & 27 & 18 & 9 & Functional \\
\hline 16. & Dukku Dam(Kogin Dole) & EM & 15 & - & 0 & Functional \\
\hline 17. & Cham Dam & EM/RSV & 43 & 23 & 20 & Failed \\
\hline \multirow[t]{2}{*}{18.} & Waya Dam & EM(SHELL) & 24 & 17 & 7 & Failed (rptdly) \\
\hline & & $\mathrm{EM}(\mathrm{CORE})$ & 21 & - & - & \\
\hline \multirow[t]{2}{*}{19.} & Gubi Dam & EM(SHELL) & 23 & - & 0 & Functional \\
\hline & & $\mathrm{EM}(\mathrm{CORE})$ & 18 & - & 0 & \\
\hline 20. & Miri Dam & EM/RSV & 22 & 15 & 7 & Distressed \\
\hline 21. & Marraraba Ganye Toro Dam & EM/RSV & 23 & 17 & 6 & Functional \\
\hline \multirow[t]{2}{*}{22.} & Dull Dam & EM(Left) & 27 & 19 & 8 & Failed \\
\hline & & EM(Right) & 29 & 19 & 10 & \\
\hline
\end{tabular}

KEY; EM = Embankment, RSV = Reservoir, SPLW = Spillway

Compaction; Optimum Moisture Content (OMC) and Maximum Dry Density (MDD)

In Table 5, the range of values for the OMC (\%) and MDD $\left(\mathrm{Mg} / \mathrm{m}^{3}\right)$ of the failed dams were $7.6-13.2$ and $1.64-1.84$. These values show a wide range of behavior for the soil under compaction from coarse-grained non cohesive to finegrained cohesive material. The values of OMC and MDD for the distressed dams range from 8.7 to 10.7 and 1.75 to 2.01 respectively. This depicts materials from coarsegrained non-cohesive to fine-grained cohesive soils. The
OMC and MDD of the functional dams were also found to follow a similar trend with values ranging from $6.5-11.7$ and $1.65-2.00$ respectively signifying embankment materials from coarse-grained non-cohesive soil to finegrained cohesive material. There is an obvious overlap in the values of MDD and OMC from the results of the standard proctor compaction tests for all the dams in the study area. Most functional dams (80\%) have MDD of 1.84 $\mathrm{Mg} / \mathrm{m}^{3}$ and above. This shows that the denser the embankment soil materials the more the stability.

Table 5. Compaction Test Results

\begin{tabular}{|c|c|c|c|c|c|}
\hline $\mathrm{S} / \mathrm{N}$ & Name of Dam & $\begin{array}{l}\text { Soil Sample } \\
\text { location }\end{array}$ & $\begin{array}{l}\text { Optimum Moisture } \\
\text { Content,OMC (\%) }\end{array}$ & $\begin{array}{l}\text { Maximum Dry } \\
\text { Density, MDD } \\
\left(\mathrm{Mg} / \mathrm{m}^{3}\right)\end{array}$ & Status \\
\hline \multirow[t]{3}{*}{1.} & Girei & SPLW & & & Failed \\
\hline & & EM & 10.5 & 1.80 & \\
\hline & & RSV & - & - & \\
\hline \multirow[t]{2}{*}{2.} & Guyaku GR Dam 2 & RSV & - & - & Failed \\
\hline & & EM & 10.4 & 1.82 & \\
\hline \multirow[t]{2}{*}{3.} & Guyaku GR Dam 5 & IN GULLY & - & - & Failed \\
\hline & & EM & 11.2 & 1.80 & \\
\hline 4. & Nzuzu Dam & SPLW & 7.6 & 1.84 & Failed \\
\hline 5. & NGGR Dam 1(Dalehi) & EM & 10.7 & 1.75 & Distressed \\
\hline 6. & NGGR Dam 2(Dalehi) & RSV & - & - & Failed \\
\hline 7. & Ali Walga Dam & EM & 6.5 & 2.00 & Functional \\
\hline 8. & SBGR Dam 3 & RSV & - & - & Distressed \\
\hline \multirow[t]{2}{*}{9.} & SBGR Dam 4 & EM & 8.7 & 2.01 & Distressed \\
\hline & & RSV & - & - & \\
\hline
\end{tabular}




\begin{tabular}{|c|c|c|c|c|c|}
\hline 10. & Dadinkowa Dam & EM & 11.2 & 1.84 & Functional \\
\hline 11. & Bambam Dam & EM & 12.2 & 1.56 & Failed \\
\hline 12. & Pindiga Dam I & EM/RSV & 8.4 & 1.87 & Functional \\
\hline 13. & Pindiga Dam II & EM/RSV & 11.7 & 1.65 & Functional \\
\hline 14. & Bojude & EM/RSV & 9.7 & 1.84 & Functional \\
\hline 15. & Jombo Dam Dukku & EM/RSV & 10.8 & 1.70 & Functional \\
\hline 16. & Dukku Dam(Kogin Dole) & EM & 7.2 & 1.91 & Functional \\
\hline 17. & Cham Dam & EM/RSV & 13.2 & 1.64 & Failed \\
\hline \multirow[t]{2}{*}{18.} & Waya Dam & EM(SHELL) & 10.8 & 1.96 & Failed (rptdly) \\
\hline & & $\mathrm{EM}(\mathrm{CORE})$ & 10.2 & 1.83 & \\
\hline \multirow[t]{2}{*}{19.} & Gubi Dam & EM(SHELL) & 6.7 & 1.89 & Functional \\
\hline & & $\mathrm{EM}(\mathrm{CORE})$ & 10.2 & 2.00 & \\
\hline 20. & Miri Dam & EM/RSV & 9.4 & 1.88 & Distressed \\
\hline 21. & Marraraba Ganye Toro Dam & EM/RSV & 9.5 & 1.94 & Functional \\
\hline \multirow[t]{2}{*}{22.} & Dull Dam & EM(Left) & 8.8 & 1.84 & Failed \\
\hline & & EM(Right) & 8.9 & 1.95 & \\
\hline
\end{tabular}

KEY; EM = Embankment, RSV = Reservoir, SPLW = Spillway

\section{Soil Texture (Sieve Analysis)}

The classes of soil found in the construction materials of the failed dams include poorly graded sand (SP), well graded sand (SW), uniformly graded sands of low plasticity ( SPSC) and non-plastic well graded silty sands of low plasticity (SW-SM). This shows a wide range of soil materials that can exhibit a wide range of behavior when used as construction materials for earth dams. The distressed dams were found to have been constructed with poorly graded sands (SP), well graded sands (SW) and well graded silty sands of low plasticity (SW-SM). This also shows that the distressed dam's construction materials vary widely from poorly graded sands to well graded silty sands of low plasticity. The soil materials for the functional dams include poorly graded sands (SP), well graded sands (SW) and uniformly graded silty sands of low plasticity (SP-SM). Embankment soil materials with Coefficient of uniformity of less than 5 accounted for about $79 \%$ of the failures and distresses. This implies that there is lack of finer particles in the soil that can help in cementation.

\section{CONSOLIDATION SETTLEMENT}

The average settlement of failed dam soil materials was found to be $2.29 \mathrm{~mm}$ while that of a functional dam was found to be $1.18 \mathrm{~mm}$, meaning that more settlement was recorded for the failed dam than functional dam. Hence, the weaker the soil the greater the chances of failure. This also agrees with Adejumo et al. (2012) on their work on major weak soils.

In summary a wide range of soil groups were used for construction of earth dams in north-eastern Nigeria. This ranged from poorly graded sands to Silty/Clayey sands. The soils are good enough to be used as construction materials for earth dams. Dams whose embankment soil materials have Specific gravity (Gs) of 2.63 and below exhibited greater $(92 \%)$ failures and distresses than those with higher Gs. This means that the cleaner the soil grains the less will be the cementing effects between them. Embankment soil materials with Coefficient of uniformity of less than 5 accounted for about $79 \%$ of the failures and distresses. This means that, uniform graded soil lack the finer particles and intermediate particles that help in binding the soil together. Sixty five percent of failed and distressed dams have their
Plasticity index (PI) values between 0 and 7 meaning failures were recorded in embankments with low plasticity. Most functional dams (80\%) have high MDD of $1.84 \mathrm{mg} / \mathrm{m}^{3}$ and above. This shows that the denser the embankment soil material the more stable will be the embankment. Good percentage of the failed dams $(33 \%)$ have their embankment soil materials with coefficient of permeability between $1.21 \times 10^{-6} \mathrm{~m} / \mathrm{s}$ to $2.10 \times 10^{-7} \mathrm{~m} / \mathrm{s}$, suggesting the susceptibility of such dams to seepage failure.

The Properties of soil can influence failure, distressnes or functionality of earth dams in conjunction with other engineering factors (feasibility studies, design and construction), geological factors and hydrometreological conditions.(Umaru, 2014, Umaru et al. 2014; 2015)

The soil tests results were analyzed with respect to failure, distressnes and functionality using ANOVA. The result shows that there are no significant differences in the soil properties with respect to status of the dams in the study area. In categorical terms, soil properties alone cannot determine failure, distressnes or functionality of earth dams in the study area, because geology as well as hydrometreology also has effects on the status of the dams as suggested by Umaru, (2014) and Umaru et al. (2014; 2015)

\section{REFERENCES}

[1] Adejumo T. W, Alhassan M. and Boiko I. L. (2012); Physicomechanical Properties of Some Major Weak Soils in Nigeria. Electronic Journal of Geotechnical Engineering. Vol. 17 pp2435-2441Retrieved $10^{\text {th }}$ May, 2013from EJGE.

[2] Adeniji F. A. (2003). Re advocating Conservation of Soil and Water Resources for Sustainable Development in North Eastern Nigeria..Proceedings of the $4^{\text {th }}$ Intrnational Conference of the Nigerian Society of Agricultural Engineers Volume 25. pp7-16.

[3] ADSO (2011); Association of State Dam Safety Officials. Dam Failure Investigation Guideline. Dam Failure Investigation Committee. U.S.A.

[4] Agarwal Y.C. (2000).Design of Small Earth Dams, Technical memo, Water Resources Department Government of Rajasthan, Jaipur India.1-6.Retrieved Mar. 16, 2008 from www.mhtml:file://E:IGuidelines.mht.

[5] Arora, K.R (2001). Irrigation water power and water resources engineering. Naisarak India:Standard publishers. 
[6] Brink,A.B.A,T.C. Batridge and A.B. William (1982) .Soil Survey for Engineers(monograph on soil and resources survey). New York: Oxford University press.

[7] BS \{1377(1990)\} (2003); British Standard- Methods of Tests for Soils for Civil Engineering Purposes. Technical Information Services CNL.

[8] Garg K. S. (2008). Irrigation Engineering and Hydraulic Structures. $21^{\text {st }}$ rev. ed. New Delhi, India. Khanna Publishers Delhi.

[9] Lukman S, Otun J. A, Adie D. B, Ismail A and Oke I. A (2011). A Brief Assesment of a Dam and its Failure Prevention. Journal of Failure Analysis and Prevention. Vol. 11 pp.97-109

[10] Murthy V.N.S (2008). A text book of Soil Mechanics and Foundation Engineering. $1^{\text {st }}$ ed.New Dilhi, Bangalore. India. CBS publishers \& distributors

[11] Obiefuna G. I, Nur A, Baba A. U. and Bassey N. E. (1999); Geological and Geotechnical Assesment of Selected Gully Sites, Yola north-eastern Nigeria. Journal of Environmental Hydrology. Vol. 7 Paper 6 pp1-13.

[12] Oskoorouchi A. M and A. Mehdibeiji (1986). How ought one to Determine Soil Parameters to be used in the Design of Earth and Rock fill dams. Indian Geotechnical Conference Volume 2. pp. 11-13.

[13] Punmia B. C. and Lal P. B. B. (1992). Irrigation and Water Power Engineering. $12^{\text {th }}$ ed. J udpur India. Laxmi Pupblications (P) Ltd.

[14] Sherard J.L (1953). Influence of soil properties and construction methods on the performance of homogeneous earth dams. Denver: US Bureau of reclamation Technical memo no: 645.

[15] Singh, A. (2001). Soil Engineering in theory and practice. Volume 1. Fourth Edition. CBS Publishers and Distributors. Dryaganj, New Delhi, India.

[16] Umaru A., Ogedengbe K. and Omobowale M. O. (2010); Structural Failures of Earth Dams in Nigeria: A Case Study of Cham Dam in Gombe State. ARPN Journal of Engineering and Applied Sciences. Vol. 5 No. 11 pp. $48-52$

[17] Umaru, A. B. (2014); Influence of Engineering Properties of the Soil, Geological and Hydrometerology factors on Failures and Distress of Earth Dams in North-eastern Nigeria. Unpublished Ph.D Thesis, Department of Agricultural and Environmental Engineering, University of Ibadan, Ibadan Nigeria.

[18] Umaru A. B., Sangodoyin A. Y. and Oke I. A. (2014). On the Causes and Effects of Earth Dams Failures in North-Eastern Nigeria. International Journal of Engineering Research and Technology. Vol. 3. No. 2. pp. 2978 - 2985

[19] Umaru A. B., Sangodoyin A. Y. and Oke I. A. (2015). On the Effects of Geological and Hydrometreological Factors on Failures and Distresses of Earth Dams Failures in NorthEastern Nigeria. IMPACT; International Journal of Research in Engineering and Technology. Vol. 3. No. 6. pp. $37-46$.

[20] Wrechien D. de and Mambretti (2009). Dam-break Problems, Solutions and Case Studies. WIT eLibrary. WITpress Southampton, Boston USA.

[21] Yohana J.K,Fulani A.U,Azakagu E.D and Anda A.D (2003).Prospects of using Anthill Materials for the Control of Seepage in Earth Dams.Proceedings of the $4^{\text {th }}$ Intrnational Conference of the Nigerian Society of Agricultural Engineers Vol. 25 pp. 135-143. 